\title{
Effects of School Proximity on Students' Performance in Mathematics
}

\author{
Emerson D. Peteros ${ }^{1 *}$, Shiela C. Ypil ${ }^{2}$, John V. de Vera ${ }^{3}$, Gerly A. Alcantara ${ }^{4}$, \\ Margie D. Fulgencio ${ }^{1}$, Dennis B. Plando ${ }^{1}$, Larry B. Peconcillo Jr. ${ }^{3}$ \\ ${ }^{1}$ College of Education, Cebu Technological University-Main Campus, Cebu City, Cebu, Philippines \\ ${ }^{2}$ Math Instructor, Lamac National High School, Lamac, Pinamungajan, Cebu, Philippines \\ ${ }^{3}$ College of Education, Cebu Technological University-Naga Extension Campus, City of Naga, Cebu, Philippines \\ ${ }^{4}$ College of Education, Cebu Technological University-Danao Campus, Danao City, Cebu, Philippines \\ Email: *emerson.peteros@ctu.edu.ph, sheilamae.cabilino@deped.gov.ph, john.devera@ctu.edu.ph, \\ margie.fulgencio@ctu.edu.ph,dennis.plando@ctu.edu.ph, larry.peconcillojr@ctu.edu.ph
}

How to cite this paper: Peteros, E. D., Ypil, S. C., de Vera, J. V., Alcantara, G. A., Fulgencio, M. D., Plando, D. B., \& Peconcillo Jr., L. B. (2022). Effects of School Proximity on Students' Performance in Mathematics. Open Journal of Social Sciences, 10, 365-376.

https://doi.org/10.4236/jss.2022.101028

Received: December 30, 2021

Accepted: January 24, 2022

Published: January 27, 2022

Copyright $\odot 2022$ by author(s) and Scientific Research Publishing Inc. This work is licensed under the Creative Commons Attribution International License (CC BY 4.0).

http://creativecommons.org/licenses/by/4.0/

\begin{abstract}
This research investigated the school proximity and the Grade 7 students' academic performance in Math of a mountain barrio public national high school in Pinamungajan, Cebu, Philippines. There were 171 respondents who were identified using simple random sampling. They answered a survey questionnaire describing their proximity to the school while their Fourth Quarter Grades were used to assess their academic performance in Math. Data gathered were treated using descriptive and inferential statistics. Results revealed that most of the students are very far from school which they have to walk to reach school. Most of their houses are not accessible to the road. They had a very satisfactory performance in Math. Moreover, there was a significant relationship between the students' distance to school and their academic performance in Math. However, no significant relationships between the student's mode of transportation, house accessibility to the road, and their academic performance in Math were found. Thus, it is recommended that school administrators and teachers design programs that would address students' challenges in attending school relative to their house to school distance while the government provides infrastructures that would address concerns on long-distance travel of the students.
\end{abstract}

\section{Keywords}

School Proximity, School Distance, Mode of Transportation, Road Accessibility, Academic Performance in Math 


\section{Introduction}

One of the United Nations Educational, Scientific and Cultural Organization (UNESCO) Seventeen Goals ensures that by 2030 every learner obtains the information and skills necessary to promote ecological development, as well as among others through education for bearable development and ecological routines, human rights, sexual role fairness, advancement of a culture of peace and non-violence, world citizenship and appreciation of cultural variety of culture's impact to viable development (UNESCO, 2015). Hence, students from different places must be given access to equitable education (Parveen \& Awan, 2019). Relative to these goals, Philippines had established public schools in different far flung areas even with less transportation and communication technology to make education accessible to students living in these areas in order to address the basic right of children to education (Human Rights Watch, 2016). However, schools in the mountain areas are still less accessible for students because of poor infrastructure (Limaye, 2016). In infrastructure, Philippines stay behind in terms of road connectivity, exposure to risky drinking water, adeptness of train services, and electrification rate. This shows that there is still wide range of areas that are not yet developed (Dayrit et al., 2018). Thus, students attending school need to walk long distance because of the absence of roads passable by motor vehicles since there are still lots of people who choose to have their living in rural areas (Gebre \& Gebremedhin, 2019). In the absence of these infrastructures, people become isolated and participate less in information exchanges. In most cases, problems encountered by the people and schools located in these areas are not addressed by the government because of other government priorities (Organisation for Economic Co-operation and Development [OECD], 2012).

Consequently, students' poor academic performance has been linked with the location of schools in a community based on some investigations. Students' poor scholarly accomplishment is explicitly linked with the students' distance from school. There is a great impact between the distance of the school and the academic performance of the students as they regularly go to school. Long distances trekked by students from their homes to school made them tardy and with empty stomachs which could result in school dropouts (Mhiliwa, 2015). Moreover, students who have to walk daily at a lengthy distance from their home to school spend less time studying and sleeping leading them to be waking up late in the morning. Besides, walking long distances is physically and mentally tiring (Zuckerman, 2021). Some of them reach school sweat-soaked, pushed and depleted, both physically and mentally (Wheaton, Chapman, \& Croft, 2016). As a result, it is harder for them to focus on studying after they get home, and it can lead to low performance in school (Matingwina, 2018). Distance from school is one of the hindrances to learning that students in rural areas are facing. This always happens to students living in rural areas with the absence of accessible road. Moreover, the lack of time for students to study at home can also contribute to their difficulties towards learning the subjects they find difficult to learn. 
Most students consider math as a difficult subject which results in poor performance in the subject (Gafoor \& Kurukkan, 2015).

Students' poor performance in mathematics continues to be a problem in education. Although a lot of factors may have contributed to this (Brew, Nketiah, \& Koranteng, 2021), few have explored the distance travelled by students to school, mode of transportation in going to school and the accessibility of their house to the road as the other reasons why students perform poorly in school (Baliyan \& Khama, 2020). Most of the students who are affected by these factors live in rural areas where infrastructures are less developed. Thus, students living in these areas struggle to survive in attending school. They often encounter difficulties in learning their subjects, particularly in math due to less time in studying and being physically tired.

These concerns which are prevalent in the Philippines have been less explored by the researchers. There are many schools in the Philippines which are established in rural areas with less infrastructure, poor communication, no electricity, no accessible roads and isolated residential settlements. This home environment has influence on the academic performance of the students especially when they are exposed to poverty and live in environment with fewer opportunities and resources for learning (Brew, Nketiah, \& Koranteng, 2021). Students in these areas oftentimes face these challenges while attending school. Among these challenges is the long-distance walk to school because roads going to school are not passable by motor vehicles. Students who are exposed to these challenges while attending school often encounter physical and mental fatigue which could affect their performance in school especially on subjects that are difficult to learn like Math. It is in this context that this study is crafted to examine the relationship between school proximity and students' academic performance in Math. The findings may provide salient information to stakeholders which could help in minimizing the challenges of students in far flung areas in attending school.

\section{Literature Review}

This research utilized different literature and reviews to explore the interplay of the variables using the existing literature relevant to the study conducted. The following are as follows:

Every country made efforts to make education accessible to all because education is significant in the country's development. However, these efforts differ in every country (Getachew, 2018). In developing countries like the Philippines, poor quality of education is linked to different factors such as the school and community (Saeed, 2003). The population that the school caters and the distance that students need to travel everyday is one the important aspects that the government needs to consider in building schools (Duze, 2010). In rural areas where people living in the community are from each other, school distance is oftentimes the problem for students because they need to travel long distances everyday to reach school. There are two modes that students can travel in going to 
school such as the passive and active modes. Passive mode of travelling refers to transporting through motorized vehicles while active mode refers to walking or cycling (Baliyan \& Khama, 2020). In mountain areas where there are few road infrastructures, passive mode of travelling is not always applicable for students. This results to walking long distances to reach school. A distance of one or more than one kilometer of walking is considered a long distance walk for students. Students who are in this situation in order to attend school could suffer the adverse effects of long distance walking (Duze, 2010; Thomas, 2016).

Students who are very far from school will have difficulties in completing outside-school tasks because of the time spent walking from school to home and vice versa (Waswa, 2015; Nelson, Misra, Sype, \& Mackie, 2016). Other than that, students who need to walk long distances would results to arriving home or school late aside from experiencing fatigue and hunger (Onderi, Kiplangat, \& Awino, 2014). A considerable amount of energy is lost when students are exposed to walking at long distances and can also lead to poor concentration on their school tasks, promote absenteeism and school drop-outs (Marique, Dujardin, Teller, \& Reiter, 2013; Moyo, 2013; Taiwo, 2019). For students who are far from school, they need to wake up early while they can return home late which sacrifices their time for studying. This could also affect their sleep patterns (Pradhan \& Sinha, 2017).

Mhiliwa (2015) investigated the degree to which distance influenced the scholastic accomplishment of the students in secondary schools in Makambako Town Council. Results revealed that more extended distance traveled by the students to school made them late and with empty stomachs. The school distance has disappointed students because of the long walk they have to take in order to reach school.

Moyo (2013) analyzed the impacts of walking over long distance to and from school. It was found out that long distance travel will result to arriving school late and at home after school late at night. It was additionally clarified that on account of longer walking, exhaustion and hunger lead students to fatigue during learning. Additionally, walking at stretched out distance to class essentially make students arrive at schools with empty stomachs and delay influencing badly, their academic performance.

Baliyan and Khama (2020) investigated the impact of distance to school of the 168 students in Botswana on their performance in mathematics. Results revealed that distance to school has significant impact on their mathematics performance. Further, the Post Hoc analysis revealed that long travelling distance had negative impact on the students' math performance. Thus, they recommend that students stay closer to school and have reliable school transportation. Moreover, Duze (2010) examined the average distance travelled to school by students in primary and secondary schools in the three states of Nigeria and its effect on attendance. Results revealed that majority of the students travelled up to five kilometers which had negative effects on their attendance. 
Ebinum et al. (2017) investigated the relationship between school distance and academic achievement of primary school pupils in Ovia North-East LGA. Results revealed that the pupils travelled long distance to school. Further, the test revealed a significant relationship between school distance and academic achievement of male primary school pupils while no significant relationship for the female primary school pupils. It was recommended that the primary schools be located in strategic locations to lessen the distance travelled by the pupils.

Moreover, there are different research findings regarding the effects of school location on the academic performance of the students in mathematics. School location is categorized here as rural and urban schools. Schools in the rural areas have concerns on their proximity such as the distance from the residents and accessibility. Alordiah, Akpadaka, and Oviogbodu (2015) stressed that students from the rural areas who are attending schools encounter more challenges than students from urban schools which greatly affects their performance in mathematics. Owoeye and Yara (2011) added that students' school location influence their academic performance in school in which rural areas are characterized by poor school mapping, lack of passable roads and students' unwillingness to attend school because of their isolated villages. However, many research findings argued that students' school location does not influence their performance in mathematics (Ezeudu \& Obi, 2013; Ezeudu et al., 2014; Ntibi \& Edoho, 2017; Osadebe \& Oghomena, 2018). Hence, there is no established literature that would answer concerns regarding this matter.

At present, no research was found specifically investigating the effects of distance to school, mode of transportation, and the students' house accessibility to the road to the academic performance of the students in the Philippines. Yet, a lot of schools are built in mountain areas of the country having issues on students' transportation. Thus, it is imperative to explore such factors to provide relevant information on issues related to this matter.

\section{Materials and Methods}

This study utilized a descriptive correlational research design which aimed to test the relationship between the students' school proximity and their academic performance in Math. The correlational design is a strategy in which the researcher is trying to test the relationship among variables without trying to manipulate any of them (Strangor \& Walinga, 2014). Before determining the relationship, the students' proximity to school and their academic performance in Math were evaluated. There were 171 out 299 Grade 7 students who participated and were identified using simple random sampling. A simple random is a subset of a factual populace where every individual from the subset has an equivalent likelihood of being picked. A basic arbitrary inspecting is intended to be a fair portrayal of a gathering (Hayes, 2021). Slovin's formula was used to determine the appropriate number of respondents who participated in the study. The Grade 7 students are the most appropriate respondents because they are in the 
transition period from primary to secondary. Primary schools in the Philippines are located in the nearby community. This is contrary to secondary schools wherein such schools are built only in more populated mountain barrios. Thus, when the pupils are promoted to secondary they need to transfer enrolment to another school located in a larger barrio. Here, school proximity becomes an issue for the students. Grade 7 students need to adapt to the new mode of schooling and the lessons they encounter in school. Assessing the effects of school proximity to the academic performance of these students can provide crucial information for the success of providing quality education for the children of the country.

A survey questionnaire that elicits information related to the students' proximity to school in terms of distance to school, mode of transportation, and accessibility to the road was used. The distance from home to school was measured using 3 levels; 0 - $2 \mathrm{~km}-$ Very close, $3 \mathrm{~km}-5 \mathrm{~km}-$ Far, $6 \mathrm{~km}$-above-Very Far. For the mode of transportation students were provided with choices which are common modes of transportation in the students' place while the accessibility of their house was determined through the presence of roads passable by motor vehicles. An informed consent and assent was secured before the questionnaires were distributed to the students. Students were oriented on the purpose of the study and were given enough time to answer the questionnaires. A 100\% retrieval rate of the questionnaires was achieved by the researchers. On the other hand, the Fourth Quarter Grades of the students in Math were used to describe their academic performance. Retrieval of these data was assisted by the adviser of the students using their school records. Data gathered were treated using descriptive statistics such as frequency count and percentage to determine the categories in which the respondents belong based on the measured variable. Chi-square test for independence was utilized to test the relationship of the students' school proximity and performance in Mathematics.

\section{Results and Discussion}

This section presents the data gathered in terms of the students' school proximity, their academic performance in Math and the relationship of these variables. The data on school proximity is reflected in Table 1.

As presented in Table 1, there were 65 or 38.01 percent of the students who are living $6 \mathrm{~km}$ and beyond from school which is considered very far from school. In the same table, there were 124 or 72.51 percent of the students who would walk from home to school while there were 47 or 27.49 percent of them ride on a motorcycle upon going to school. On the other hand, there were 90 or 52.63 percent of the respondents living in areas not accessible to the road while there were 81 or 47.37 percent of them were in areas accessible to the road. With these data, it can be inferred that most of the students need to walk to school for they are living in areas not accessible to the road as an additional challenge from being very far from school. Traveling a long distance has noteworthy impact on 
Table 1. School proximity of the students.

\begin{tabular}{ccc}
\hline School Proximity & $\mathrm{f}$ & $\%$ \\
\hline Distance to School (in km) & 65 & 38.01 \\
\hline Very Far (6 km and beyond) & 54 & 31.58 \\
Far $(3-5 \mathrm{~km})$ & 52 & 30.41 \\
Very Close $(0-2 \mathrm{~km})$ & 171 & 100.00 \\
Total & & \\
\hline Mode of Transportation & 47 & 27.49 \\
Motorcycle & 124 & 72.51 \\
Walking & 171 & 100.00 \\
Total & 81 & 47.37 \\
\hline Accessibility to the Road & 90 & 52.63 \\
Not Accessible & 171 & 100.00 \\
Total & & \\
\hline
\end{tabular}

students' class participation. Some students miss classes in the first part of the day and leave school early just to go home safe. Walking at a long distance is physically and mentally tiring which leads to low performance in school. Students who are tired will become less motivated to participate in school activities most especially if there were challenges that hinder them from going to school like the long distance walk, bad terrain and weather. Evidently, most of the students walk in going to school. This is due to limited access to the road, muddy terrain, or their house is in the middle of rice fields to reach school which force them to walk to school despite of the long distance the travel. Moreover, most students do not have extra money for the fare in transportation through motorcycle rides.

Table 2 presents the academic performance of the students in Math using the Department of Education (DepEd) performance rating scale.

As reflected in Table 2, there were 69 or 40.35 percent of the respondents had a very satisfactory performance and 58 or 33.92 percent of them had an outstanding performance. However, there were 8 or 4.69 of them had only fairly satisfactory performance. Students' fairly satisfactory performance is already an indicator that they are at risk of failing subject. Relative to this, DepEd implements Alternative Delivery Mode which is designed to make the school system more comprehensive and flexible, particularly for children who are at risk, hard to reach, and those students who were having trouble managing their school attendance. Nevertheless, there were still students whose performance still needs improvement. Most of them were living $6 \mathrm{~km}$ and beyond from school. They were the students who walk long distance to school and at risk of dropping-out. Hence, distance between the school and the family residence has, on average, a negative effect on the academic performance of the students (Vieira, 2015). 
Table 2. Performance level of the students in Math.

\begin{tabular}{cccc}
\hline Level & Grade Range & $\mathrm{f}$ & $\%$ \\
\hline Outstanding & $90-100$ & 58 & 33.92 \\
Very Satisfactory & $85-89$ & 69 & 40.35 \\
Satisfactory & $80-84$ & 36 & 21.05 \\
Fairly Satisfactory & $75-79$ & 8 & 4.69 \\
Did not meet the Expectations & Below 75 & -- & -- \\
Total & & 171 & 100.00 \\
Average & & \multicolumn{2}{c}{87.2} \\
\hline
\end{tabular}

Table 3. Correlation analysis between school proximity and academic performance of the students in Math.

\begin{tabular}{|c|c|c|c|c|c|}
\hline Variables & $\mathrm{df}$ & $\chi^{2}$-value & $p$-value & Decision & Remarks \\
\hline $\begin{array}{c}\text { Distance and Academic } \\
\text { Performance }\end{array}$ & 6 & $19.18^{*}$ & 0.004 & Reject Ho & Significant \\
\hline $\begin{array}{l}\text { Mode of Transportation } \\
\text { and Academic Performance }\end{array}$ & 3 & 5.77 & 0.123 & $\begin{array}{c}\text { Do not } \\
\text { Reject Ho }\end{array}$ & $\begin{array}{c}\text { Not } \\
\text { Significant }\end{array}$ \\
\hline $\begin{array}{c}\text { Accessibility and Academic } \\
\text { Performance }\end{array}$ & 3 & 4.23 & 0.237 & $\begin{array}{c}\text { Do not } \\
\text { Reject Ho }\end{array}$ & $\begin{array}{c}\text { Not } \\
\text { Significant }\end{array}$ \\
\hline
\end{tabular}

${ }^{*}$ significant at $p<0.05$.

As shown in Table 3, the test on the relationship between the school proximity and the academic performance of the students in Math using Chi-square test shows that distance $\left(\chi^{2}=19.18, p=0.004\right)$, mode $\left(\chi^{2}=5.77, p=0.123\right)$, and accessibility $\left(\chi^{2}=4.23, p=0.237\right)$ at 0.05 significance level. The results suggest that there is significant relationship between the school distance and the students' academic performance in Math. However, the mode of transportation and the road accessibility are not significantly related to the academic performance of the students in Math.

Among the three indicators of school proximity, the students' distance to school was found to have effects on their math performance in school. The data showed that most of the students are very far from school which they have to walk to reach school. Students who need to walk to reach school spend most of their time traveling rather than arriving school early in order to prepare for the day's class. Further, these students arrive in school physically and mentally tired due to the long hours traveling which can affect their performance (Bashaiza, 2016). Besides, long distance travels can contribute to irregular attendance of students to school affecting their learning (Williams, 2010). Students who have to engage in long distance walking will arrive school very tired which results to poor concentration during classes failing to grasp the lessons they need to learn for the day because learning effectively requires students to be relaxed and undisturbed by inner and outer stimuli (David, 2014). 


\section{Conclusion}

Based on the findings, it can be concluded that the students' distance from school affects their math performance. However, it was not established that the mode of transportation and road accessibility affect the students' math performance. Most of the students are living very far from their school where they need to walk to reach school because of the road inaccessibility. The challenges that students meet every day while attending school due to long-distance travel can make them physically and mentally exhausted which leads to poor performance. With these results, there is a need for the government to address the issue of students' distance from school. Although the Philippine government had made efforts in establishing secondary schools in different rural areas to make education accessible to people, long-distance travel for students remains a challenge in these areas because of scattered settlements particularly in mountain barrios making school allocation which are easily accessible for students remained unachievable. Nevertheless, this problem which has negative effects on students' performance has to be prioritized by stakeholders so that providing high-quality education to every child may be achieved.

\section{Conflicts of Interest}

The authors declare no conflicts of interest regarding the publication of this paper.

\section{References}

Alordiah, C. O., Akpadaka, G., \& Oviogbodu, C. O. (2015). The Influence of Gender, School Location and Socio-Economic Status on Students' Academic Achievement in Mathematics. Journal of Education and Practice, 6, 130-136. https://files.eric.ed.gov/fulltext/EJ1079759.pdf

Baliyan, S. P., \& Khama, D. (2020). How Distance to School and Study Hours after School Influence Students' Performance in Mathematics and English: A Comparative Analysis. Journal of Education and e-Learning Research, 7, 209-217. http://www.asianonlinejournals.com/index.php/JEELR/article/view/1899 https://doi.org/10.20448/journal.509.2020.72.209.217

Bashaiza, J. (2016). Performance: Why Distance to School Matters. https://www.newtimes.co.rw/section/read/201440

Brew, E. A., Nketiah, B., \& Koranteng, R. (2021). A Literature Review of Academic Performance, an Insight into Factors and Their Influences on Academic Outcomes of Students at Senior High Schools. Open Access Library Journal, 8, 1-14.

https://doi.org/10.4236/oalib.1107423

David, N. M. (2014). Determinants of the Poor Academic Performance of Secondary School Students in Sumbawanga District. Master's Thesis, Sokoine University of Agriculture. http://www.suaire.sua.ac.tz/handle/123456789/622

Dayrit, M. M., Lagrada, L. P., Picazo, O. F., Pons, M. C., \& Villaverde, M. C. (2018). The Philippines Health System Review Vol. 8, No. 2. World Health Organization, Regional Office for Southeast Asia.

Duze, C. (2010). Average Distance Travelled to School by Primary and Secondary School Students in Nigeria and Its Effect on Attendance. African Research Review, 4, 378-388. 
https://doi.org/10.4314/afrrev.v4i4.69236

Ebinum, U. S., Akamagune, N. E., \& Ugbong, B. I. (2017). The Relationship between School Distance and Academic Achievement of Primary School Pupils in Ovia North-East Lga, Edo State, Nigeria. International Journal of Advanced Research and Publications, 1, 427-435. http://paper.researchbib.com/view/paper/167623

Ezeudu, F. O., \& Obi, T. N. (2013). Effect of Gender and Location on Students' Achievement in Chemistry in Secondary Schools in Nsukka Local Government Area of Enugu State, Nigeria. Research on Humanities and Social Sciences, 3, 50-55.

https://www.semanticscholar.org/paper/Effect-of-Gender-and-Location-on-Students'-i n-in-in-Ezeudu-Theresa/8fcaeff4108b44210a90d6b8fc9da55da9dc8324

Ezeudu, S. A., Gbendu, G. O., \& Umeifekwem, J. E. (2014). School Location versus Academic Achievement in Geography: Does Reflective Inquiry Instructional Techniques Has Effect? PAR/PEX. Indian Journal of Research, 3, 209-216.

https://www.semanticscholar.org/paper/School-Location-Versus-Academic-Achieveme nt-In-\%3A-Ezeudu/d675e8f550229ecd4bec4e1a54c523b93df5ed9a

Gafoor, K. A., \& Kurukkan, A. (2015). Why High School Students Feel Mathematics Difficult? An Exploration of Affective Beliefs.

https://www.semanticscholar.org/paper/Why-High-School-Students-Feel-Mathematics -Difficult-Gafoor-Kurukkan/d7c3f5b301b569c9caca64fce97ebb3688744d75 https://files.eric.ed.gov/fulltext/ED560266.pdf

Gebre, T., \& Gebremedhin, B. (2019). The Mutual Benefits of Promoting Rural-Urban Interdependence through Linked Ecosystem Services. Global Ecology and Conservation, 20, e00707. https://doi.org/10.1016/j.gecco.2019.e00707

Getachew, B. (2018). Factors Affecting Student's Academic Performance in Ahuntegen General Secondary School, North Wollo Zone, Ethiopia. Journal of Education and Learning, 12, 198-206. https://doi.org/10.11591/edulearn.v12i2.8404

Hayes, D. (2021). Simple Random Sample. https://www.investopedia.com/terms/s/simple-random-sample.asp

Human Rights Watch (2016). The Education Deficit Failures to Protect and Fulfill the Right to Education in Global Development Agendas.

https://www.hrw.org/sites/default/files/accessible_document/educationdeficit0616_acc essible.pdf

Limaye, S. (2016). Factors Influencing the Accessibility of Education for Children with Disabilities in India. Global Education Review, 3, 43-56.

https://files.eric.ed.gov/fulltext/EJ1115090.pdf

Marique, A.-F., Dujardin, S., Teller, J., \& Reiter, S. (2013). School Commuting: The Relationship between Energy Consumption and Urban Form. Journal of Transport Geography, 26, 1-11. https://doi.org/10.1016/j.jtrangeo.2012.07.009

Matingwina, T. (2018). Health, Academic Achievement and School-Based Interventions. In B. Bernal-Morales (Ed.), Health and Academic Achievement. IntechOpen. https://doi.org/10.5772/intechopen.76431

Mhiliwa, J. A. (2015). The Effects of School Distance on Students' Academic Performance: A Case of Community Secondary Schools in Makambako Town Council. Master's Thesis, The Open University of Tanzania. http://repository.out.ac.tz/1296

Moyo, W. (2013). Causes and Effects of Poverty on Academic Achievements of Rural Secondary School Students: Case of Tshazi Secondary School in Insiza District. International Journal of Asian Social Science, 3, 2104-2113.

https://archive.aessweb.com/index.php/5007/article/view/2568

Nelson, D., Misra, K., Sype, G. E., \& Mackie, W. (2016). An Analysis of the Relationship 
between Distance from Campus and GPA of Commuter Students. Journal of International Education Research, 12, 37-46. https://doi.org/10.19030/jier.v12i1.9565

Ntibi, J. E., \& Edoho, E. A. (2017). Influence of School Location on Students Attitude towards Mathematics and Basic Science. British Journal of Education, 5, 76-85. https://www.eajournals.org/wp-content/uploads/Influence-of-School-Location-on-Stu dents-Attitude-towards-Mathematics-and-Basic-Science.pdf

OECD (2012). Equity and Quality in Education: Supporting Disadvantaged Students and Schools. OECD Publishing. https://doi.org/10.1787/9789264130852-en

Onderi, H., Kiplangat, R. K., \& Awino, J. (2014). Factors Contributing to Poor Academic Performance in Kenya Certificate of Secondary Education in Public Secondary Schools in Kericho Sub-County, Kericho County, Kenya. Kenyan Journal of Educational Planning, Economic and Management, 7, 1-14.

http://ir.jooust.ac.ke/handle/123456789/9479

Osadebe, P. U., \& Oghomena, D. E. (2018). Assessment of Gender, Location and Socio-Economic Status on Students' Performance in Senior Secondary Certificate Examination in Mathematics. International Education Studies, 11, 98-109. https://doi.org/10.5539/ies.v11n8p98

Owoeye, J. S., \& Yara, P. O. (2011). School Location and Academic Achievement of Secondary School in Ekiti State, Nigeria. Asian Social Science, 7, 170-175. https://doi.org/10.5539/ass.v7n5p170

Parveen, I., \& Awan, R. (2019). Equitable Higher Education: Students' Perspective on Access to Resources, Participation, and Educational Outcomes. Bulletin of Education and Research, 41, 185-201. https://files.eric.ed.gov/fulltext/EJ1217921.pdf

Pradhan, R. K., \& Sinha, N. (2017). Impact of Commuting Distance and School Timing on Sleep of School Students. Sleep and Biological Rhythms, 15, 153-158. https://doi.org/10.1007/s41105-017-0091-0

Saeed, K. A. (2003). Quality in Higher Education and Universities. In National Conference on Quality Assurance in Education in Pakistan. Pakistan Institute of Quality Control Lahore.

Strangor, C., \& Walinga, J. (2014). Introduction to Psychology-1st Canadian Edition. BCcampus.

https://opentextbc.ca/introductiontopsychology/chapter/2-2-psychologists-use-descrip tive-correlational-and-experimental-research-designs-to-understand-behavior/

Taiwo, O. R. (2019). Impact of School Plants Planning on Primary School Pupils' Academic Performance. International Journal of Advanced Academic Research/Arts, Humanities and Education, 5, 83-90.

https://www.ijaar.org/articles/Volume5-Number9/Arts-Humanities-Education/ijaar-ah e-v5n9-sep19-p30.pdf

Thomas, C. A. (2016). Going the Distancel: How Distance to School Relates to Student Education Outcomes. Doctoral Dissertation, University of California. https://escholarship.org/uc/item/97f0n3mq

UNESCO (2015). Sustainable Development Goal 4 and Its Targets. https://en.unesco.org/education2030-sdg4/targets

Vieira, I. (2015). Students Perception of the Effect of Distance from the Family Home on Academic Performance? An Exploratory Analysis. In Proceeding of International Academic Conferences. International Institute of Social and Economic Sciences.

Waswa, A. W. (2015). Factors Affecting Girl-Child Progression Rates in Primary Schools in ASAL Areas: A Survey of West Pokot Sub County in West Pokot County Kenya. Doctoral Dissertation, Moi University. 
http://ir.mu.ac.ke:8080/xmlui/bitstream/handle/123456789/117/Waswa\%20Ambrose\% 20Wawire\%202015.pdf? sequence $=1$ \&isAllowed $=y$

Wheaton, A. G., Chapman, D. P., \& Croft, J. B. (2016). School Start Times, Sleep, Behavioral, Health, and Academic Outcomes: A Review of the Literature. Journal of School Health, 86, 363-381. https://doi.org/10.1111/josh.12388

Williams, D. T. (2010). The Rural Solution: How Community Schools Can Reinvigorate Rural Education. Center for American Progress.

Zuckerman, D. (2021). Early Morning Classes, Sleepy Students, and Risky Behaviors. https://www.center4research.org/early-morning-classes-sleepy-students-risky-behaviors 